\title{
Epidemiology of cough in relation to China
}

Kefang Lai, Jiayu Pan, Ruchong Chen, Baojuan Liu, Wei Luo and Nanshan Zhong*

\begin{abstract}
Cough is one of the most common complaints for which patients seek medical attention. Misdiagnosis and mistreatment of cough exist commonly in China. The prevalence of acute cough caused by upper airway infection fluctuates between $9 \%$ and $64 \%$ in the community, for chronic cough, the prevalence $>10 \%$ in most surveys, ranging from 7.2\%-33\%. The common causes of chronic cough are upper airway cough syndrome (previously called as post nasal drip syndrome [PNDS]), cough variant asthma (CVA), gastroesophageal reflux related cough (GERD) and eosinophilic bronchitis (EB). There is a regional discrepancy regarding the prevalence of common causes of cough and distribution of gender among China, UK, USA, the most common cause of chronic cough in China are CVA, followed by UACS, EB and atopic cough (AC), the male is almost equal to female in numbers in China. The risk factors for cough includes cold air, smoking, environmental pollutants, noxious substances and allergens, and unreasonable diet habits.
\end{abstract}

Keywords: Cough, Epidemiology, Etiology, Risk factor, Quality of life

\section{Background}

Cough is the most common complaint in outpatient clinics. Based on its duration, cough can be divided into three classifications: acute cough $(<3 \mathrm{wk})$, subacute cough (3-8wk), and chronic cough ( $>8 \mathrm{wk})$. In the US, nearly 30 million people seek evaluation for cough at outpatient clinics every year [1]. Approximately $12 \%$ of people in Britain are bothered by chronic cough daily or weekly [2]. Chronic cough severely impairs their quality of life. Patients with chronic cough visited outpatient clinic six times on average [3]. It has been estimated that 360 million dollars are spent on over-the-counter (OCT) medications for chronic cough in the US every year, and the total amount of money spent on the treatment of cough globally is enormous (> 10 billion dollars) [2]. Although no surveys on economic burden caused by chronic cough have been conducted in China, we postulate that the situation is not better than that in America. In China, $80.82 \%$ patients were diagnosed with chronic bronchitis or laryngitis antibiotics are commonly used in $91.58 \%$ patients with chronic coughs [4]. This review will focus on four different aspects of cough, including the prevalence, etiology, risk factors, and influence on quality of life.

\footnotetext{
* Correspondence: nanshan@vip.163.com

State Key Laboratory of Respiratory Diseases, 1st Affiliated Hospital,

Guangzhou Medical College, Guangzhou, GZ, China
}

\section{Prevalence of cough}

Acute cough is one of the most common symptoms in respiratory out patient clinic, the common cause is an acute upper airway infection. Therefore, to some extent, the prevalence of acute upper airway infection can represent the prevalence of acute cough. The prevalence of cough caused by upper airway viral infection fluctuates between $9 \%$ and $64 \%$ [5]. In patients having sore throat, $50 \%$ complain of cough [6].

Despite of the differences of surveyed population and criteria, many surveys on the prevalence of cough revealed a high incidence, which is commonly $>10 \%$ (Table 1). Barbee et al. carried out a survey on the communities in Arizona and found out the prevalence of chronic cough was $18 \%$ [7]. The survey conducted in Italy showed that the incidence of chronic cough was $11.9 \%$ [8]. A survey in Switzerland reported that the prevalence of chronic cough in smokers was 3 times higher than non-smokers [9]. In southeast England, 16\% of interviewees spent half of their time coughing, 13.2\% of them reported productive cough, and over half of them (54\%) smoked [10]; A cross-sectional international population survey conducted in 16 European countries involving 18277 interviewees revealed that the prevalence of chronic cough was $33 \%$, and that of nocturnal cough was $30 \%$ [11]. However, this study did not differentiate between acute cough and chronic cough, and the 
Table 1 Prevalence of cough in different regions

\begin{tabular}{|c|c|c|c|c|}
\hline Surveys & Region & $\mathbf{N}$ & Definition of chronic cough & Prevalence(\%) \\
\hline \multirow[t]{2}{*}{ Barbee RA [7] (1991) } & Arizona & \multirow[t]{2}{*}{1109} & \multirow{2}{*}{$\begin{array}{l}\text { Having cough or phlegm on most days, } \\
\text { as much as } 3 \text { months of the year, lasting } \\
\text { for } \geq 2 \text { years }\end{array}$} & \multirow[t]{2}{*}{18} \\
\hline & US & & & \\
\hline \multirow[t]{2}{*}{ Lundback B [14] (1991) } & Norrbotten & \multirow[t]{2}{*}{6610} & & \multirow[t]{2}{*}{11} \\
\hline & Sweden & & & \\
\hline Cullinan P [10] (1993) & southeast England & 9077 & $\begin{array}{l}\text { Cough every day or one-half of the days } \\
\text { in a year. }\end{array}$ & 16 \\
\hline \multirow[t]{2}{*}{ Ludviksdottir D [15] (1996) } & Uppsala & \multirow[t]{2}{*}{623} & \multirow{2}{*}{$\begin{array}{l}\text { Usually cough or production of phlegm in } \\
\text { the morning during day or night in the } \\
\text { winter }\end{array}$} & \multirow[t]{2}{*}{11} \\
\hline & Sweden & & & \\
\hline \multirow[t]{2}{*}{ Zemp E [9] (1999) } & 8 areas & \multirow[t]{2}{*}{9651} & \multirow{2}{*}{$\begin{array}{l}\text { Usually cough during the day or at night, } \\
\text { on most days for as much as } 3 \text { months } \\
\text { each year. }\end{array}$} & Smoker: 9.2 \\
\hline & Switzerland & & & Nonsmoker:3.3 \\
\hline \multirow[t]{2}{*}{ Coultas DB [16] (2001) } & 81 counties & \multirow[t]{2}{*}{5743} & \multirow{2}{*}{$\begin{array}{l}\text { Having cough or phlegm on most days } \\
\text { for } \geq 3 \text { consecutive months per year }\end{array}$} & \multirow[t]{2}{*}{9.3} \\
\hline & US & & & \\
\hline \multirow[t]{2}{*}{ Janson C [11] (2001) } & 16 countries & \multirow[t]{2}{*}{18277} & \multirow{2}{*}{$\begin{array}{l}\text { Usually cough or production of phlegm in } \\
\text { the morning or during the day or night in } \\
\text { the winter }\end{array}$} & \multirow[t]{2}{*}{33} \\
\hline & Europe & & & \\
\hline \multirow[t]{2}{*}{ Cerveri I [8] (2003) } & 9 areas & \multirow[t]{2}{*}{18000} & \multirow{2}{*}{$\begin{array}{l}\text { Having cough and phlegm on most days } \\
\text { for as much as } 3 \text { months per year and for } \\
\text { at least } 2 \text { successive years }\end{array}$} & \multirow[t]{2}{*}{11.9} \\
\hline & Italy & & & \\
\hline \multirow[t]{2}{*}{ Carter ER [17] (2006) } & Seattle & \multirow[t]{2}{*}{2397} & \multirow{2}{*}{$\begin{array}{l}\text { Having a daily cough or phlegm as often as } \\
3 \text { months out of the year. }\end{array}$} & \multirow[t]{2}{*}{7.2} \\
\hline & US & & & \\
\hline \multirow[t]{2}{*}{ Ford AC [12] (2006) } & Yorkshire & \multirow[t]{2}{*}{4003} & \multirow{2}{*}{$\begin{array}{l}\text { Experienced bouts or spasms of coughing in } \\
\text { the previous } 2 \text { months. }\end{array}$} & \multirow[t]{2}{*}{12} \\
\hline & UK & & & \\
\hline \multirow[t]{2}{*}{ Lai KF [13] (2006) } & Guangzhou & \multirow[t]{2}{*}{1087} & Cough lasting for $>8$ weeks & 10.9 \\
\hline & China & & & \\
\hline
\end{tabular}

high prevalence of nocturnal cough might have resulted from the design of some questions. The first crosssectional survey on the prevalence of chronic cough was undertaken in West Yorkshire. A total of 36 general practices and nearly 4000 patients were involved in the study. After analyzing the bouts or spasms of coughing at a frequency between once a week and once or more a day in the last 2 months, Ford et al. reported that the prevalence of chronic cough was 12\% [12]. A cough survey conducted in 1087 college students in South China revealed a prevalence of $10.9 \%$ with $7.6 \%$ acute cough and $3.3 \%$ chronic cough. No difference was found between male and female. The patients with chronic cough tend to present more likely as the sole or predominant symptom as compared with the patients with acute cough [13]. Since the college students have better health status and life style, we assumed the prevalence of cough could be much higher in the community.

Lai et al. investigated previous diagnosis and management of 558 outpatients with chronic cough in South China, found that the average number of visits for medical service was more than 20 for each patients [18]. More than $80 \%$ of the patients were misdiagnosed as "bronchitis, chronic bronchitis or pharyngitis". Antibiotics was given in about $90 \%$ of the patients. The results of the latest multicenter survey in China shows the incidence of using antibiotics previously was $69 \%$ in patients with chronic cough [19].

Cough is a most common symptom in children as well. Munyard and Bush reported that healthy children coughed 10 times everyday on average, the cough occurs most often in the daytime [20]. About $10 \%-22 \%$ of children aged 5-11 years had chronic cough in the absence of colds $[21,22]$. Some surveys demonstrated the prevalence of chronic cough in children 6-12 years of age was between $5 \%$ and $10 \%$ with a higher incidence in younger children [23,24]. Chronic cough occurred in $50 \%$ of children whose parents smoked [25].

\section{Etiology of cough}

There are few reports on the spectrum of causes of acute cough and subacute cough. It is generally considered that the common cold is the most common cause of acute cough, followed by acute bronchitis. The causes of acute cough include acute exacerbation of chronic respiratory diseases (bronchiectasis, chronic bronchitis and COPD), noxious material and allergen-induced cough. Acute cough occasionally indicates some severe 
diseases such as pulmonary embolism, pneumonia and congestive heart failure, etc. Postinfectious cough is thought to be the most common cause of subacute cough. Kwon et al. evaluated 184 patients with subacute cough, found that postinfectious cough was in approximately $48 \%$ of the cases, followed by postnasal drip syndrome (33\%) and cough variant asthma (16\%) [26].

Irwin et al. [27] first set up an anatomic-diagnostic protocol for chronic cough in 1981, showed that the common causes of chronic cough were upper airway cough syndrome (UACS, termed as postnasal drip syndrome previously), bronchial asthma and gastroesophageal reflux disease (GERD). Some investigations in Europe and America have similar results on causes of chronic cough $[28,29]$.

In 1989, Gibson et al. first reported 7 patients with eosinophilic bronchitis (EB), who presented with chronic cough, eosinophilia in induced sputum, normal airway responsiveness, and a good response to corticosteroids [30]. By adding the processing of induced sputum to the diagnostic algorithm of chronic cough, Brigthling et al. found that eosinophilic bronchitis was an important cause of chronic cough in 13\% of patients [31]. Others studies from Australia, Korean, and Turkey also showed the proportion of EB to be 7-33\% of patients presenting with chronic cough [32-34], In South China, Lai et al. reported that $\mathrm{EB}$ was the most common cause of chronic cough (22\%), followed by PNDS (17\%), CVA (14\%), and GER (12\%) [35]. Early studies in North China [36] and East China [37] showed EB was not as common as that in South China. This difference on causes may be due to various diagnosis proceeds. In a latest prospective, multicenters survey on causes of chronic cough in China, EB was identified to be one of the common causes in all regions, ranging from $9.4 \%-24.2 \%$ with a mean proportion of $17.2 \%$ [19]. EB has been formally proposed as one of common causes in the guideline on chronic cough by European Respiratory Society (ERS) [38], Chinese Medical Association [39], and American College of Chest Physicians (ACCP) [40]. Therefore, EB as a common cause of chronic cough has been recognized globally.

In the US or Europe, GERD is a common cause of chronic cough, however, GERD is found to be only a minor cause of chronic cough in Asia: 2\% in Japan [41] and $4.6 \%$ in China [19]. The lower incidence of GERDrelated cough might be related to the lower incidence of GERD in Asia as compared with the US or Europe [42]. In contrast to typical Western life style, the Asian dietary consists of high content of fiber, grains and vegetables. A diet rich in fiber has been reported to decrease the risk of cough [43].

Atopic cough (AC) was defined first by Fujimura in Japan as a bronchodilator-resistant dry cough associated with sputum eosinophilia or an atopic predisposition
[44,45], and was reported being a common cause of chronic cough in Japan. AC reported in Japan overlap with EB in fact. The definition of AC in China is different from that of Japan since the patients with eosinophilia in induced sputum were excluded in China. Although the concept of $\mathrm{AC}$ remains controversial and is not widely accepted,many patients with atopic predisposition are seen in our clinics, and the cough can be relieved by corticosteroids or antihistamine therapy. Two regional surveys in Guangzhou and Shenyang, a Southern and a Northern region of China respectively, show a proportion of approximately $12 \% \mathrm{AC}$ in patients with chronic cough $[35,46]$. Recently, a prospective, multicenter survey in China found that AC was identified in $13.2 \%$ of patients with chronic cough [19].

Idiopathic cough (or unexplained cough) would not be considered until a thorough diagnostic and treatment approach for the common causes of cough have been completed and uncommon causes are adequately evaluated [47]. The incidence of idiopathic cough is not uncommon in some studies $[48,49]$. In China, the unexplained cough accounted for $8.4 \%$ of the cases in a latest multicenter survey [19]. It is still unclear whether some unexplained cough (idiopathic cough) represents a single entity or includes certain undiscovered causes of chronic cough. Those idiopathic cough are more common in middle age women and perimenopause women, characteristiced by being hypersensitive to smoke, dust, cold air and other stimulants, increased cough sensitivity, no causes could be identified in spite of many investigation. Recently, a new single discrete clinical entity termed as 'cough hypersensitivity syndrome' was introduced. It was postulated that the new term would focus on the problem on the cough symptomatology and lead to a better understanding of the mechanisms of cough sensitization [50,51].

Although epidemiological surveys in the community show a high incidence of chronic bronchitis, the hospitalbased studies on the etiology of chronic cough have shown that the proportion of these patients is only $4 \%-7 \%$ [27,28] (Table 2).

Angiotensin converting enzyme inhibitor (ACEI)induced cough should be noted predictively in the elderly. Because the incidence of cardiovascular disease is associated with age, elderly people are might expected to have ACEI-induced cough more frequently [55].

The common causes of chronic cough in children vary according to different age groups [56]. Acute respiratory infection and protracted bacterial bronchitis are the most common causes for infant and early children [57]. Allergy and asthma become predominant causes during the school years [58]. Foreign body aspiration is much more common in infant than adults. Gastroesophageal reflux during infancy is a physiological phenomenon with an occurrence rate of $40 \%$ to $65 \%$, reaching a peak 
Table 2 Causes of chronic cough in different regions

\begin{tabular}{|c|c|c|c|c|c|c|}
\hline & $\mathrm{N}$ & Asthma & PNDS & GERC & EB & Other causes \\
\hline \multicolumn{7}{|l|}{ USA } \\
\hline Irwin RS [27] (1980) & 49 & $25 \%$ & $29 \%$ & $10 \%$ & & CB $12 \%$ \\
\hline Poe [52] (1989) & 139 & $35 \%$ & $26 \%$ & $5 \%$ & / & CB 7\% \\
\hline Irwin RS [28] (1990) & 102 & $24 \%$ & $41 \%$ & $21 \%$ & / & CB 5\% \\
\hline Mello [29] (1996) & 88 & $14 \%$ & $38 \%$ & $40 \%$ & / & / \\
\hline \multicolumn{7}{|l|}{ UK } \\
\hline Brightling CE [31] (1999) & 91 & $18 \%$ & $24 \%$ & $8 \%$ & $13 \%$ & \\
\hline Birring SS [53] (2004) & 236 & $17 \%$ & $12 \%$ & $15 \%$ & $7 \%$ & PIC 7\% \\
\hline Kastelik JA [54] (2005) & 131 & $24 \%$ & $6 \%$ & $22 \%$ & / & PIC 8\% \\
\hline \multicolumn{7}{|l|}{ Australia } \\
\hline Carney IK [32] (1997) & 30 & $23 \%$ & $73 \%$ & $93 \%$ & $10 \%$ & ACEI 23\% \\
\hline \multicolumn{7}{|l|}{ Turkey } \\
\hline Ayik S [34] (2003) & 36 & $3 \%$ & $22 \%$ & $22 \%$ & $33 \%$ & PIC 6\% \\
\hline \multicolumn{7}{|l|}{ Japan } \\
\hline Fujimura M [41] (2005) & 176 & $36 \%$ & $18 \% *$ & $2 \%$ & / & AC $29 \% \#$ \\
\hline \multicolumn{7}{|l|}{ Korea } \\
\hline Joo JH [33] (2002) & 92 & $16 \%$ & $33 \%$ & / & $12 \%$ & CB 15\% \\
\hline \multicolumn{7}{|l|}{ China } \\
\hline Yang ZM [37] (2005 Shanghai) & 105 & $51.4 \%$ & $26.7 \%$ & $1.9 \%$ & $5.7 \%$ & PIC 8.5\% \\
\hline Lai KF [35] (2006 Guangzhou) & 194 & $14 \%$ & $17 \%$ & $12 \%$ & $22 \%$ & AC $12 \%$ \\
\hline Lu GL [36] (2009 Beijing) & 123 & $33.3 \%$ & $24.4 \%$ & $20.3 \%$ & $4.9 \%$ & AC $3.3 \%$ \\
\hline Lai KF [19] (2012) & 704 & $32.6 \%$ & $18.6 \%$ & $4.6 \%$ & 17.2 & AC $13.2 \%$ \\
\hline
\end{tabular}

Abbreviations: PNDS Post-nasal drip syndrome, GERC Gastroesophageal reflux-related cough, EB Eosinophilic bronchitis, AC Atopic cough, PIC Post-infectious cough, CB chronic bronchitis, ACEI ACEl-related cough.

\# The definition of atopic cough in Japan is somewhat different from that in China.

in infants of 1 to 4 months, and this eases after age of 1 year. It is debatable whether GERD is a common cause of chronic cough in children. Chang et al. found a low incidence of GERD related to chronic cough in children [24]. However, a high incidence of GERD related chronic cough was reported in another study [58]. There are few reports concerning the incidence of EB in children with chronic cough. In China, the epidemiological surveys concerning chronic cough in children are lacking. Zhao et al. analyzed the causes of chronic solitary cough in 50 children aged 6-12 years, finding that 20 were PNDs 17 CVA, 5 postinfectious cough, 4 psychogenic cough, 1 primary gastroesophageal reflux disease and 2 EB [59].

\section{Risk factors for cough}

Cold air, cigarette smoking, allergens, environmental pollutants, various noxious substances, poor diet habit and female gender may contribute to cough.

\section{Cold air}

The winter season is the peak period of incidence for respiratory diseases [60]. It might due to direct the simulating effect of cold air on airway mucosa and the cough reflex. In addition, the lower temperature increases the replication and spread of respiratory viruses. A long-life cohort study from 1998 to 2007 observed the seasonal variation of cough and showed that the proportion of subjects reporting cough was significantly higher in winter and fall, than in other seasons. In the winter season, levels of elemental carbon and NO2 in ambient air were significantly are associated with cough [61].

\section{Cigarette smoking and exposure to tobacco smoke}

Both cigarette smoking and exposure to tobacco smoke are risk factors for cough, including dry cough, productive and nocturnal cough [9]. Regular smokers have a much higher prevalence of chronic cough than never smokers and ex-smokers $[7,9]$, whereas smokers generally disregard cough and refuse to seek medical assistance. In survey of Charlton et al., definite link was found between parental smoking in the home and increasing risk of coughs in young children [25].

\section{Diet habits}

Poor dietary habits such as long-term fat-diet and excessive stimulating food or coffee may induce relaxation of 
the lower esophageal sphincter, and lead to gastroesophageal reflux [62]. Compared with Asia, a higher prevalence of GERD (10-22\%) [27,28,53,54] is found in Europe and Unite States as compared with Asia (2-12\%) $[19,35,41]$, which may be related to long-term high fatdiet and coffee intake in Europe and America. The effect of lifestyle modification (including losing weight and low fat-diet) on decreasing the prevalence of GERD has been noted [63].

\section{Environmental pollution}

Exposure to increasing particulate matter (PM10) is associated with increased respiratory symptoms such as cough, phlegm and sore throat, and is likely to induce or worsen cough [64]. It was noted that PM10 increased the odds of cough and phlegm in school students aged 11-20 years old in Hong Kong [65]. A cohort study in Switzerland demonstrated that the prevalence of cough decreased with a fall of ambient PM10 concentration [66]. Chronic cough was more common among those subjects living close to heavy traffic compared to those not living close to heavy traffic [67]. An Italian study indicated that an increased prevalence of cough in females was due to air pollution [68]. Excessive exposure to nitrogen dioxide was also found to be a risk factor for cough [9]. In the heavy industrial province of Northeastern China, the high level of outdoor air pollution, such as TSP, $\mathrm{SO}_{2}$ and $\mathrm{NO}_{2}$ were positively associated with the increasing prevalence of chronic cough in children [69].

\section{Allergen}

There is evidence that allergen is a potential coughrelated factor. Gehring and co-workers noted that indoor exposure to Dermatophagoides farinaeantigen and cat antigen increase the risk of nocturnal cough [70]. Allergic diseases such as EB and CVA might be induced due to exposure to pollen and dust mite, as well as occupational exposure to chemical agents [71-73].

\section{Gender}

Among patients attending specialist cough clinics, females exceed males in number [74]. ACEIs cause cough in $5-20 \%$ of patients who receive them, and females are more susceptible than males [75]. Studies have shown that chronic persistent nonproductive cough is more frequent in females [44,76]. Cough affects females more often than males, and females are more easily troubled by symptoms of cough. The cough threshold is lower in females than in males, illustrating that the cough sensitivity is heightened in females [77,78]. This gender difference of cough is not very obvious in China, the numbers of male is almost equal to female $[4,13,35]$. The mechanism underlying the gender differences in cough is still unclear, and additional research is needed to better understand gender differences in coughs.

\section{The influences of cough on quality of life}

Chronic cough can lead to physiological disorder, psychological stress and disrupt social life. Complications induced by cough involve the respiratory, cardiovascular, digestive, genitourinary, musculoskeletal and nervous systems. An increasing prevalence of complications is in line with an aggravating and prolonged cough [79]. Thoracoabdominal pain caused by the damage of muscle fibers, as well as hoarseness due to vocal cords damage, are common in clinic. Many women with chronic cough experience urinary incontinence [80]. In China, Yang et. al reported that chronic cough seriously interfered with the patient's quality of life, which shows no gender difference. However, women have urinary incontinence with a proportion of about $50 \%$ [81].

Chronic cough impact seriously quality of life on physiological, psychological and social aspects. Questionnaires are used to comprehensively assess impact of cough on quality of life, such as Cough-Specific Quality of Life Questionnaire (CQLQ) [82], Leicester Cough Questionnaire(LCQ) [83] and Chronic Cough Impact Questionnaire (CCIQ) [84]. In addition to physiological complications, patients with chronic cough experience psychological imbalance and social predicament. Patients suffer from embarrassing emotion caused by prolonging cough, they feel anxious about the cough and prejudices from others, which may aggravate their psychological condition [82]. Among patients with chronic cough in New York, 53\% of them experience depression, indicating that depression is a common incidental symptom [85]. Psychological symptoms are often relieved with inmprovement of chronic cough [84]. A survey in Guangzhou showed that patients with an average duration of 4 years of cough are also troubled with mental and social problems, one-half of patients feel embarrassed and annoyed, and greater than one-quarter feel upset and even depressed [86].

\section{Conclusion}

Cough is one of the most common complaints for which patients seek medical attention. Health-care expenditure for managing cough is substantial and quality of life can be severely affected. The prevalence of acute cough is 9 to $64 \%$ in the community. The prevalence of chronic cough is $>10 \%$ in most countries or regions, ranging from $7.2 \%-33 \%$. The common causes of chronic cough are upper airway cough syndrome, cough variant asthma, gastroesophageal reflux-related cough and eosinophilic bronchitis. There are regional discrepancies about the common causes of chronic cough, gastroesophageal reflux-related cough in China and Japan is 
not so common as in Europe and America, and atopic cough is more common in China and Japan. The risk factors of cough includes cold air, smoking, environmental pollutants, noxious substances and allergens, and unhealthy dietary habits.

\section{Competing interests}

The authors declare that they have no competing interests.

\section{Authors' contributions}

NSZ and KFL conceived the study and set up the task groups of the authors. All authors conducted the literature review. KFL, JYP, RCC, BJL, and WL created the draft of the paper. All authors read and approved the final manuscript.

\section{Authors' information}

KFL:M.D., Ph.D. Professor of Internal Medicine, State Key Laboratory of Respiratory Diseases, 1st Affiliated Hospital of Guangzhou Medical College, and Ph.D. tutor of respiratory medicine. JYP: M.D., State Key Laboratory of Respiratory Diseases, 1st Affiliated Hospital of Guangzhou Medical College. RCC: M.D., Ph.D. State Key Laboratory of Respiratory Diseases, 1 st Affiliated Hospital of Guangzhou Medical College. BJL: M.D., State Key Laboratory of Respiratory Diseases 1st Affiliated Hospital of Guangzhou Medical College. WL: Master's degree in immunology, Senior Research Fellow, State Key Laboratory of Respiratory Diseases, 1st Affiliated Hospital of Guangzhou Medical College. NSZ: Academician of Chinese Academy of Engineering, Professor of Internal Medicine, State Key Laboratory of Respiratory Diseases, 1st Affiliated Hospital of Guangzhou Medical College, and Ph.D. tutor of respiratory medicine.

\section{Acknowledgements}

The authors thank Dr. Binkai Li from the Guangzhou First People's Hospital for data collection.

Received: 25 January 2013 Accepted: 22 June 2013

Published: 8 July 2013

\section{References}

1. Woodwell DA: National ambulatory medical care survey: 1998 summary. Hyattsville, MD: National Center for Health Statistics; 2000

2. Moriee AH: Chronic cough: Epidemiology. Chron Respir Dis 2008, 5:43-47.

3. Everett CF, Kastelik JA, Thompson RH, Morice AH: Chronic persistent cough in the community: A questionnaire survey. Cough 2007, 3(1):5.

4. Lai KF, Li BK, Wang FX, Chen RC, Liu XY, Zhong NS: Survey on the diagnosis and management of the patients with chronic cough. Int $J$ Respir 2011, 31:645-647.

5. Tyrrell DA, Cohen S, Schlarb JE: Signs and symptoms in common cold. Epidemiol Infect 1993, 111:143-156.

6. Eccles R, Loose I, Jawad M, Nyman L: Effects of acetylsalicylic acid on sore throat pain and other pain symptoms associated with acute upper respiratory tract infection. Pain Med 2003, 4:118-124.

7. Barbee RA, Halonen M, Kaltenborn WT, Burrows B: A longitudinal study of respiratory symptoms in a community population sample. Correlations with smoking, allergen skin-test reactivity, and serum lgE. Chest 1991, 99:20-26.

8. Cerveri I, Accordini S, Corsico A, et al: Chronic cough and phlegm in young adults. Eur Respir J 2003, 22:413-417.

9. Zemp E, Elsasser S, Schindler C, Künzli N, Perruchoud AP, Domenighetti G, Medici T, Ackermann-Liebrich U, Leuenberger P, Monn C, Bolognini G, Bongard JP, Brändli O, Karrer W, Keller R, Schöni MH, Tschopp JM, Villiger B, Zellweger JP: Long-term ambient air pollution and respiratory symptoms in adults (SAPALDIA study). Am J Respir Crit Care Med 1999, 159:1257-1266.

10. Cullinan P: Aetiological factors in persistent sputum production: a casecontrol study. J Epidemiol Community Health 1993, 47:27-31.

11. Janson C, Chinn S, Jarvis D, Burney P: Determinants of cough in young adults participating in the European Community Respiratory Health Survey. Eur Respir J 2001, 18:647-654.

12. Ford AC, Forman D, Moayyedi P, Morice AH: Cough in the community: a cross sectional survey and the relationship to gastroin-testinal symptoms. Thorax 2006, 61:975-979.
13. Chen RC, Lai KF, Liu CL, Luo W, Zhong NS: An epidemiologic study of cough in young college students in Guangzhou. Chin J Epidemiol 2006, 27:123-126.

14. Lundback B, Nystrom L, Rosenhall L, Stjernberg N: Obstructive lung disease in northern Sweden: respiratory symptoms assessed in a postal survey. Eur Respir J 1991, 4:257-266.

15. Ludviksdottir D, Bjornsson E, Janson C, Boman G: Habitual coughing and its associations with asthma, anxiety, and gastroesophageal reflux. Chest 1996, 109:1262-1268.

16. Coultas DB, Mapel D, Gagnon R, Lydick E: The health impact of undiagnosed airfl ow obstruction in a national sample of United States adults. Am J Respir Crit Care Med 2001, 164:372-377.

17. Carter ER, Debley JS, Redding GR: Chronic productive cough in school children: prevalence and associations with asthma and environmental tobacco smoke exposure. Cough 2006, 2:11.

18. Lai KF, Li BK, Wang FX, Chen RC, Liu XY, Zhong NS: Survey on the diagnosis and management of the patients with chronic cough. Int J Respir 2011, 31:645-647.

19. Lai KF, Chen RC, Lin JT, Huang KW, Shen HH, Kong LF, Zhou X, Luo ZY, Yang $\mathrm{L}$, Wen FQ, Zhong NS: A prospective, multicenter survey on causes of chronic cough in china. Chest 2013, 143(3):613-620.

20. Munyard P, Bush A: How much coughing is normal? Arch Dis Child 1996, 74:531-534.

21. Faniran AO, Peat JK, Woolcock AJ: Measuring persistent cough in children in epidemiological studies: development of a questionnaire and assessment of prevalence in two countries. Chest 1999, 115:434-439.

22. Luyt DK, Burton PR, Simpson H: Epidemiological study of wheeze, doctor diagnosed asthma, and cough in preschool children in Leicestershire. $\mathrm{Br}$ Med J 1993, 306:1386-1390.

23. Faniran AO, Peat JK, Woolcock AJ: Persistent cough: is it asthma? Arch Dis Child 1998, 79:411-414.

24. Thomson F, Masters IB, Chang AB: Persistent cough in children-overuse of medications. J Paediatr Child Health 2002, 38:578-581.

25. Charlton A: Children coughs related to parental smoking. Br Med J (Clin Res Ed) 1984, 288:1647-1649.

26. Kwon NH, Oh MJ, Min TH, Lee BJ, Choi DC: Causes andclinical features of subacute cough. Chest 2006, 129:1142-11147.

27. Irwin RS, Corrao WM, Pratter MR: Chronic persistent cough in the adult: the spectrum and frequency of causes and successful outcome of specifi C therapy. Am Rev Respir Dis 1981, 123:413-417.

28. Irwin RS, Curley FJ, Frech CL: Chronic cough. The spectrum and frequency of causes, key components of the diagnostic evaluation, and outcome of specific therapy. Am Rev Respir Dis 1990, 141:640-647.

29. Mello CJ, Irwin RS, Curley FJ: Predictive values of the character, timing, and complications of chronic cough in diagnosing its cause. Arch Intern Med 1996, 156:997-1003.

30. Gibson GR: Enalapril-induced cough. Arch Intern Med 1989, 149:2701-2703.

31. Brightling CE, Ward R, Goh KL, Wardlaw AJ, Pavord ID: Eosinophilic bronchitis is an important cause of chronic cough. Am J Respir Crit Care Med 1999, 160(2):406-410.

32. Carney IK, Gibson PG, Murree-Allen K, Saltos N, Olson LG, Hensley MJ: A systematic evaluation of mechanisms in chronic cough. Am J Respir Crit Care Med 1997, 156:211-216.

33. Joo JH, Park SJ, Park SW, Lee JH, Kim DJ, Uh ST, Kim YH, Park CS: Clinical features of eosinophilic bronchitis. Korean J Intern Med 2002, 17:31-37.

34. Ayik SO, Basoglu OK, Erdinc M, Bor S, Veral A, Bilgen C: Eosinophilic bronchitis as a cause of chronic cough. Respir Med 2003, 97:695-701

35. Lai KF, Chen RC, Liu CL, Luo W, Zhong SQ, He MZ, Li DR, Zhong NS: Etiology and a diagnostic protocol for patients with chronic cough. Chin J Tuberc Respir Dis 2006, 29:96-99.

36. Lu GL, Lin JT: The spectrum and clinical features of causes for chronic cough. Chin J Tuberc Respir Dis 2006, 32:422-425.

37. Yang ZM, Qiu ZM, Lv HJ, Wei WL, Wang L, Liu RL: A prospective study on the causes of chronic cough. J Tongji Univ 2005, 26:62-64

38. Morice AH, Fontana GA, Sovijarvi AR, Pistolesi M, Chung KF, Widdicombe J, O'Connell F, Geppetti P, Gronke L, De Jongste J, Belvisi M, Dicpinigaitis P, Fischer A, McGarvey L, Fokkens WJ, Kastelik J: The diagnosis and management of chronic cough. Eur Respir J 2004, 24:481-492.

39. Asthma workgroup of Chinese society of respiratory diseases(CSRD): Chinese medical association :the Chinese national guidelines on diagnosis and management of cough(protocal). Chin $J$ Tuberc Respir Dis 2005, 28:738-744. 
40. Richard S, Irwin RS, Michael H, et al: American college of chest physicians (ACCP): diagnosis and management of cough executive summary ACCP evidence-based clinical practice guidelines. Chest 2006, 129:1S-23S.

41. Fujimura M, Abo M, Ogawa H, Nishi K, Kibe Y, Hirose T, Nakatsumi Y, Iwasa K: Importance of atopic cough, cough variant asthma and sinobronchial syndrome as causes of chronic cough in the Hokuriku area of Japan. Respirology 2005, 10:201-207.

42. Dent J, Becher A, Sung J, Zou D, Agréus L, Bazzoli F: Systemic review: patterns of reflux-induced symptoms and esophageal endoscopic findings in large-scal survey. Clin Gastroenterol Hepatol 2012, 10(8):863-873.

43. Butler LM, Koh WP, Lee HP, Tseng M, Yu MC, London SJ: Prospective study of dietary patterns and persistent cough with phlegm among Chinese Singaporeans. Am J Respir Crit Care Med 2006, 173(3):264-270.

44. Fujimura M, Sakamoto S, Matsuda T: Bronchodilator-resistive cough in atopic patients: bronchial reversibility and hyperresponsiveness. Intern Med 1992, 31:447-452.

45. Society JR: Prolonged and chronic cough. Respirology 2006, 11(suppl): S160-S174.

46. Si SY, Peng QF, Shi X, Kong LF: Distribution of causes and clinical features of chronic cough in Shenyang and its surrounding districts. Chin J Tuberc Respir Dis 2010, 33:862-863.

47. Haque RA, Usmani OS, Barnes PJ: Chronic idiopathic cough: a discrete clinical entity? Chest 2005, 127:1710-1713.

48. Puolijoki H, Lahdensuo A: Causes of prolonged cough in patients referred to a chest clinic. Ann Med 1989, 21:425-427.

49. Pratter MR, Bartter T, Akers S, DuBois J: An algorithmic approach to chronic cough. Ann Intern Med 1993, 119(10):977-983.

50. Morice $\mathrm{AH}$ : The cough hypersensitivity syndrome: a novel paradigm for understanding cough. Lung 2010, 188(Suppl 1):S87-S90.

51. Chung KF: Chronic 'cough hypersensitivity syndrome': a more precise label for chronic cough. Pulm Pharmacol Ther 2011, 24:267-271.

52. Poe RH, Harder RV, Israel RH: Chronic persistent cough. Expericence in diagnosis and outcome using an anatomic diagnosing its cause. Arch Intern Med 1996, 156:997-1003.

53. Birring SS, Parker D, Brightling CE, Bradding P, Wardlaw AJ, Pavord ID: Induced sputum inflammatory mediator concentrations in chronic cough. Am J Respir Crit Care Med 2004, 169:15-19.

54. Kastelik JA, Aziz I, Ojoo JC, Thompson RH, Redington AE, Morice AH: Investigation and management of chronic cough using a probabilitybased algorithm. Eur Respir J 2005, 25:235-243.

55. Wei W, Yu L, Lu H, Wang L, Shi C, Ma W, Huang Y, Qiu Z: Comparison of Cause Distribution between Elderly and Non-Elderly Patients with Chronic Cough. Respiration 2009, 77:259-264.

56. ChangAB GWB: Guidelines for evaluating chronic cough in pediatrics: ACCP evidence-hased clinical practice, idelines. Chest 2006, 129(1 Suppl):260-283.

57. Marchant JM, Masters IB, Taylor SM, Cox NC, Seymour GJ, Chang AB: Evaluation and outcome of young children with chronic cough. Chest 2006, 129(5):1132-1141B

58. Khoshoo V, Edell D, Mohnot S, Haydel R Jr, Saturno E, Kobernick A: Associated factors in children with chronic cough. Chest 2009, 136(3):811-815.

59. Zhao SY, Ren YX, Jiang ZF: Causes and diagnostic procedure of 50 children with chronic solitary cough. Chin J Pract Pediat 2006, 21(2):109-111.

60. Elliot AJ, Cross KW, Fleming DM: Acute respiratory infections and winter pressures on hospital admissions in England and Wales 1990-2005. J Public Health (Oxf) 2008, 30:91-98.

61. Patel MM, Hoepner L, Garfi Nkel R, Chillrud S, Reyes A, Quinn JW, Perera F, Miller RL: Ambient metals, elemental carbon, and wheeze and cough in New York city children through 24 months of age. Am J Respir Crit Care Med 2009, 180:1107-1113.

62. Kavuru MS, Richter JE: In Medical treatment of gastroesophageal reflux disease and airway disease, Gastroesophageal reflux disease and airway disease. Edited by Stein M. New York: Marcel Dekker; 1999:179-207.

63. Irwin RS, Zawacki JK, Wilson MM, French CT, Callery MP: Chronic cough due to gastroesophageal reflux disease: failure to resolve despite total/neartotal elimination of esophageal acid. Chest 2002, 121:1132-1140.

64. Vedal S, Petkau J, White R, Blair J: Acute effects of ambient inhalable particles in asthmatic and nonasthmatic children. Am J Respir Crit Care Med 1998, 157:1034-1043.

65. Pan G, Zhang S, Feng Y, Takahashi K, Kagawa J, Yu L, Wang P, Liu M, Liu Q, Hou S, Pan B, Li J: Air pollution and children's respiratory symptoms in six cities of Northern China. Respir Med 2010, 104(12):1903-1911.
66. Bayer-Oglesby L, Schindler C, Hazenkamp-von Arx ME, Braun-Fahrländer C, Keidel D, Rapp R, Künzli N, Braendli O, Burdet L, Sally Liu LJ, Leuenberger P, Ackermann-Liebrich U: SAPALDIA Team: Living near main streets and respiratory symptoms in adults. Am J Epidemio/ 2006, 164:1190-1198.

67. Montnemery P, Bengtson P, Elliot A, Lindholm LH, Nyberg P, Lofdahl CG: Prevalence of obstructive lung diseases and respiratory symptoms in relation to living environment and socio-economic group. Respir Med 2001, 95:744-752.

68. Viegi G, Pedreschi M, Baldacci S, Chiaffi L, Pistelli F, Modena P, Vellutini M, Di Pede F, Carrozzi L: Prevalence rates of respiratory symptoms and diseases in general population samples of North and Certral Italy. Int J Tuberc Lung Dis 1999, 3:1034-1042.

69. Lai HK, Ho SY, Wong CM, Mak KK, Lo WS, Lam TH: Exposure to particulate air pollution at different living locations and respiratory symptoms in Hong Kong-an application of satellite information. Int J Environ Health Res 2010, 20(3):219-230

70. Gehring U, Heinrich J, Jacob B, Richter K, Fahlbusch B, Schlenvoigt G, Bischof W, Wichmann HE: Respiratory symptoms in relations to indoor exposure to mite and cat allengens and endotoxins. Indoor factors and Genetics in Asthma(INGA)Study Group. Eur Respir J 2001, 18:555-563.

71. Bobolea I, Barranco P, Sastre B, Fernández-Nieto M, del Pozo V, Quirce S: Seasonal eosinophilic bronchitis due to allergy to Cupressus arizonica pollen. Ann Allergy Asthma Immunol 2011, 105(5):448-449.

72. Yacoub MR, Malo JL, Labrecque M, Cartier A, Lemière C: Occupational eosinophilic bronchitis. Allergy 2005, 60(12):1542-1544.

73. Cartier A, Sastre J: Clinical assessment of occupational asthma and its differential diagnosis. Immunol Allergy Clin North Am 2011, 31(4):717-728.

74. Irwin RS, Boulet LP, Cloutier MM, Fuller R, Gold PM, Hoffstein V, Ing AJ, McCool FD, O'Byrne P, Poe RH, Prakash UB, Pratter MR, Rubin BK: Managing cough as a defense mechanism and as a symptom: a consensus panel report of the American College of Chest Physicians. Chest 1998, 114:133S-181S.

75. Gibson GR: Enalapril-induced cough. Arch Intern Med 1989, 149:2701-2703.

76. Fujimura M, Kamio Y, Hashimoto T, Matsuda T: Cough receptor sensitivity and bronchial responsiveness in patients with only chronic nonproductive cough. in view of effect of bronchodilator therapy. Asthma 1994, 31:463-472.

77. Fujimura M, Kasahara K, Kamio Y, Naruse M, Hashimoto T, Matsuda T: Female gender as a determinant of cough threshold to inhaled capsaicin. Eur Respir J 1996, 9:1624-1626.

78. Kastelik JA, Thompson RH, Aziz I, Ojoo JC, Redington AE, Morice AH: Sexrelated differences in cough reflex sensitivity in patients with chronic cough. Am J Respir Crit Care Med 2002, 166:961-964.

79. Irwin RS: Complications of cough :ACCP evidence-based clinical practice guidelines. Chest 2006, 129:54S-58S.

80. French $C T$, Fletcher KE, Irwin RS: Gender differences in health-related quality of life in patients complaining of chronic cough. Chest 2004, 125:482-488.

81. Yang CZ, Chen RC, Li BK, Wang FX, Lai KF: Survey of quality of life and incontinence in female patients with chronic cough. Int J Respir 2010, 158 (15):391-394.

82. French CL, Irwin RS, Curley FJ, Krikorian CJ: Impact of chronic cough on quality of life. Arch Intern Med 1998, 158:1657-1661.

83. Birring SS, Prudon B, Carr AJ, Singh SJ, Morgan MD, Pavord ID: Development of a symptom specific health status measure for patients with chronic cough: Leicester cough questionnaire (LCQ). Thorax 2003 58:339-343.

84. Baiardini I, Braido F, Fassio O, Tarantini F, Pasquali M, Tarchino F, Berlendis A, Canonica GW: A new tool to assess and monitor the burden of chronic cough on quality of life: chronic cough impact questionnaire. Allergy 2005, 60(4):482-488

85. Dicpinigaitis PV, Tso R, Banauch G: Prevalence of depressive symptoms among patients with chronic cough. Chest 2006, 130:1839-1843.

86. Lai KF, Li BK, Wang FX, Zhong NS: Quality-of-life questionnaire in patients with chronic cough. Int J Respir 2011, 31:326-328.

doi:10.1186/1745-9974-9-18

Cite this article as: Lai et al:: Epidemiology of cough in relation to China. Cough 2013 9:18. 